\title{
Reflections on Kenya's national and security interests
}

\section{Macharia Munene}

\section{Introduction:}

Recent events, especially those surrounding how Kenya projects itself in the region, have attracted attention that is not necessarily favourable. This calls for a reflection on what constitutes national as well as security interests and how to protect and advance them in the midst of potentially hostile environment. The assumption by other countries that they have the right to instruct Kenya on how it should conduct its affairs is understandable in the sense that it may be in the interests of those countries to do so. That, however, is not necessarily in Kenya's interests and Kenyan officialdom should guard against falling into the trap of sacrificing national interests in order to please powerful external forces. To do this well, it is appropriate to take some concepts into account. The following are some reflections.

\section{National Interests:}

Discussing national security interests requires a thorough understanding of what the national interests to be secured are. The interplay between interest and security at any level is at the centre of any political unit, irrespective of the size of that unit. The entities in operation are geopolitical units that have defined borders called states which, over time, have acquired a self-justification that make them appear, and are then assumed, to be natural. By their very nature, states seek to protect themselves from all types of threats whether the danger is internal or external. They have become instruments through which peoples are administered and conduct their socio-economic affairs, and struggle to survive as viable entities in the midst of many challenges.

States are then "sovereign" units and each is considered to be a "nation" that has "interests" which need "security". "Security" can refer to the survival of that unit as a political entity while "interest" can refer to the values that distinguish that unit from any 
other. The two concepts compliment each other. Of the two, however, it is "interest" that takes precedence in the sense that the purpose of "security" is to secure "interests" that define a given political unit. The capacity of various political entities to provide "security" for their "interests" varies and depends on numerous factors.

Subsequently, "national interests" and "national security" are concepts that are ever present in international discourse as countries try to short-change each other. How well a country does affects its ability to secure its interests. In doing so, there appears to be roughly three elements that should be considered and that help to make clear what a country's position should be in relations to others. These include thorough knowledge of its own national philosophy and ideals, thorough knowledge of the national ideals and philosophies in other countries that might affect it, and knowledge of the points of convergence and divergence that a country has with other countries.

In this context, Kenya, as a state, must project and protect its "national interests" in a hostile international environment and be able to know the points of convergence and divergence with the interests of any other country. It is also necessary to make a distinction between primary or core and secondary interests. While secondary interests can be negotiated, the primary should not. The challenge is to know the difference so as not to give away primary interests while protecting secondary ones. Among the core interests are the sovereignty of the state and the right of the citizens to have ultimate authority on what happens, the governing structure or the constitution from which all activities including diplomacy are derived, and the security of that state.

In addition, there are other vital interests that shape the character of state. Among these is the economic well being and ability to be self-reliant. Excessive dependency on others is detrimental to national interests and tends to erode a country's its ability to act in a sovereign manner. It makes it difficult for Kenya to demand reciprocity, which is vital to national interest and sense of national security. This implies relative equality of states and entails demanding that a country's citizens are treated with as much respect in other 
places as they accord to foreigners. It is a belief that a given country is not a lesser country and that its citizens are not lesser human beings than others.

Inability to demand reciprocity also affects Kenya's image. Protecting the image of a country is an important national interest and this might call for occasional engagement in acts of symbolic toughness. Acting tough is a deterrence to would be bullies. This, however, can be done only if officials are aware of national interests and values to be protected. Countries often engage in sable-rattling, demand reciprocity, and give impression of unpredictability as acts of symbolic toughness just to safeguard their images. They do so to let other countries know, or assure citizens, that the state is not a pushover.

There are two categories of foreign forces that Kenya needs to take into account. These are geopolitical forces or the location of certain countries in relations to Kenya and the transnational forces that are not confined to geographical zones. Sometimes the two are linked and if they are hostile, they can have devastating effect on Kenya.

Each country, with itself as the centre, operates from a geographical position and its values should be understood and internalized by various operators. This would enable officials to participate effectively in advancing and protecting core values but to do that effectively, they need to be aware of Kenya's geo-strategic environment, in roughly three concentric circles. Thorough knowledge of each of the geographical circles is a way of preparing the country to deal with problems that might arise.

The First Circle refers to the country's immediate neighbours, whether the land or the sea, meaning that what happens in Uganda, Tanzania, Ethiopia, Sudan, Somalia, and the Indian Ocean has direct effect on Kenya. The required knowledge of these states include national or state ideology of each of them, the economic strength and trading patterns, the types of governance and the effectiveness of that governance, military strength and preparedness in all aspects, security intents, and potential threats to the country. These threats can be social, economic, military, social, intellectual and ideological, or in a form 
of a breakdown of socio-political order in one country that spills over to another. Thorough knowledge of these aspects about a country's immediate neighbours would help to formulate a foreign policy that would promote and protect its values.

The Second Circle refers to countries in the African continent and demands deep knowledge of continental developments that have potential impact on Kenya. This would include having command of shifting ideologies and values in some countries and detailed knowledge of the relations of other African countries to Kenya's immediate neighbours or those in the First Circle. The rationale for this is that adverse dealings from countries outside the First Circle that affect the First Circle are likely to be trans-nationalised beyond the particular country and to have an effect on Kenya. Knowledge of the Second Circle also requires identification of the relative power positions of core countries in Africa which include South Africa, Nigeria, Congo, and Egypt.

The Third Circle refers to Extra-Continental Powers or centres of power outside Africa and their potential impact on Kenya. Deep knowledge of the forces, ideals, and values behind the behaviour of countries such as the United States of America, Russia, Germany, Britain, France, China, India, Brazil, Mexico, Saudi Arabia, Iran, Japan, Israel and Korea would be a necessity. In addition, knowledge of extra-continental regional groupings and movements such as the European Union, the ASEAN, Commonwealth of Independent States, the Scandinavian zone, and Latin American groupings would be of value. This knowledge would entail analysis of the way these extra-continental forces relate to Kenya's immediate neighbours and with the rest of the African continent. Such knowledge would help members of parliament and Kenya to anticipate relations with the extra-continental powers.

Besides the geopolitical concentric circles are those forces emanating from outside the country, transcending states and are not officially under the control of any particular state. Amongst these are United Nations related organs like the Bretton-Wood Institutions, World Trade Organisations, Regional Groupings, International Media 
Houses, International Non-Governmental Organisations, Human Rights crusaders, and International Terrorism.

Many of these have little regard for states as constituted or for the leaders of those states and Kenya has been a victim of such forces. They often act as agents of post-modern colonialism in which non-state institutions that are based in powerful countries make small states and their leaders irrelevant to the exploitation of a people and to the attainment of the objectives of those external forces. As they instruct states to take specified action or be punished, they know that powerful states would back them up.

It would be in Kenya's interests, therefore, for all diplomats to have a thorough understanding of these forces that make states irrelevant by ultimately making the government of a particular place irrelevant. Diplomats should be competent in terms of knowledge and the skill of argumentation while dealing with any of these institutions. The challenge is that Kenya's opponents are often very well organized and endowed with unlimited resources to push their cause. It would, therefore, be necessary for Kenyan officials to be better prepared than the officials of those forces when it comes to any issue affecting Kenya's position. This preparedness involves complete mastery of Kenya's national ideals, values, interests, and potential threats. It also means complete mastery of the positions and arguments that are likely to be presented by any of the global institutions while pushing its agenda. Only then can Kenya deal on an equal footing with those institutions that push the ideals and values of other places.

\section{The Region}

By its very location, economic performance and socio-political disposition, Kenya has become a regional power around which other countries in Eastern Africa gravitate. It is a regional magnate that attracts all types of peoples in search of peace, refuge, or material comfort. With it come all many threats and forces of destabilization at both continental and extra-continental levels. Initially, Kenya was a victim of territorial aggression in the form of Somali irredentism in the 1960s in the form of a shifta war. 
Kenya has been and is likely to continue being part of the regional response to conflicts in the two regions. This has varied from mediations, engaging in peace keeping, and even crafting governments of national unity that is specific to a particular country. First were the challenges coming from Somalia, in its Pan-Somali dream, which supported rebel activities in Kenya and to Ethiopia. This made the two countries enter into a defense understanding and seek OAU help. It also led Somalia into a quasi-war with Kenya, called Shifta, and a real war with Ethiopia, the Ogaden War. Somalia eventually disintegrated after the 1991 ouster of President Mohammed Siad Barre.

Once the shifta war was over, Kenya's role as an absorbing sponge for people escaping turmoil in the Great Lakes and the Horn intensified. It became the focal point of conflict management in the area and was forced to try its hand in peace making in order to safeguard its interests. As refugees flocked to the country from the neighbouring Uganda, Somalia, Sudan, Ethiopia, Rwanda, Burundi, and Congo, they threatened Kenya's national security in part because of the proliferation of small arms which entered the country. These refugees were not confined to refugee camps since many of them found their way to urban areas.

The fragmentation of Somalia, for instance, essentially de-bordered Kenya and Somalia to the extent that there is a semi-official free flow of goods and people mainly in one direction. The fragmentation has also plunged Kenya into the unknown international territory of piracy where Somali pirates affect shipping in Eastern Africa. The influx of the Somali "refugees" who are not in refugee camps have effectively transformed such urban areas as Eastleagh in Nairobi. Other than the supposed availability of small arms, the amount of money available to the "refugees" has affected the national economy in a way that makes Kenyans poor because prices of basic goods have sky rocketed. It is therefore in Kenya's security as well as national interest to help restore the peace in Somalia.

Until there is a viable government in Somalia, Kenya is stack in the Somali imbroglio because Somalia is an immediate neighbour. Through IGAD, the neighbours sought to 
restore order by creating the Federal Transitional Government with elections being held in Nairobi. Transferring the Somali Government from Nairobi to Mogadishu required security given that the number of warlords to be considered was increasing, and some were comfortable in Nairobi. IGAD authorized the African Union Mission to Somalia, AMISOM, which was partially realized in 2007 and tries to keep the Federal Transitional Government afloat in the midst of opposition from Al-Shabaab and the warlords who are responsible for piracy along the Somali coast. Kenya's support for the Transitional Government is not a matter of necessity, not choice. As such, Kenya should redouble effort to train Somali functionaries while encouraging various factions to settle their differences.

Apart from Somalia, Kenya also concerned itself with Sudan where rebellion in Southern Sudan had started soon after independence. Despite many attempts at peace making, there had been no resolution. Instead, the neighbouring countries of Sudan and Uganda ended up trading accusations that each was supporting rebels. Uganda supported the Sudanese People's Liberation Army, SPLA, while Sudan supported the Lord's Resistance Army, LRA, led by Joseph Kony. Kenya helped to facilitate peace process in Sudan between the government and the SPLA, that produced the comprehensive agreement in Sudan. The Comprehensive Peace Agreement called for a power sharing formula as well as the possibility of separation. This had the effect of reducing the need for Sudan to continue using the LRA or Uganda using the SPLA as a proxies. The region remains volatile especially on the question of Somalia which calls on its neighbours to intervene and save it.

Settling the Sudan conflict was in Kenya's interest in a number of ways. As in the case of Somalia, there is the problem of refugees from Sudan who do not behave like refugees. Some have small arms that end up in the hands of criminals. The main concern in the case of Sudan, which has just gone through an election mandated by the by the 2005 Comprehensive Peace Agreement, is the build up to the 2011 referendum. The election results are as expected and the referendum is likely to lead to a new state of Southern Sudan. 
Kenya has a lot at stake in the coming referendum in both security and economic terms and the challenge is to prepare for the new state. There is possibility that the various peoples of Southern Sudan will bring their submerged differences up and might engage in protracted ethnic feuds. If this happens, Kenya should expect to receive more refugees and not less. The hope is that the new Government of Southern Sudan will be able to hold the various peoples together by giving them an acceptable ideology around which they can rally. It is in Kenya's interest to help them do that and ensure that it does not fragment like Somalia. A stable and prospering Southern Sudan will increase trading opportunity and help to spur regional economic growth with its supply of oil

Preparing for the new state also implies working hard not to antagonize the Sudanese government in Khartoum. So far, Kenya has managed to maintain cordial links with both sides which enabled it to facilitate the peace agreement. It will need to continue playing the same role, between the north and the south, after the referendum when new disputes are likely to take the centre stage. Such disputes include the boundary line and the sharing of existing natural wealth.

Other than the Horn, Kenya has interest in the Great Lakes where disputes among neighbours continue to pester. Eastern Congo is a problem to Burundi, Rwanda, and Uganda with various rebel movements trying to destabilize the governments. At different times, Kenya has had to host refugees from each of those places. And when such countries turn on each other as Rwanda and Uganda did in Eastern Congo, some of the repercussions are felt in Nairobi.

Probably one way of lessening tensions in the Great Lakes is the strengthening of the East African community by hastening the removal of political borders among the member states. Kenyans stand to benefit from the resulting free movements of goods and services in part because of their ingenuity and the existing socio-economic and communication infrastructure that makes Nairobi a regional hub for Eastern Africa. 


\section{Global Challenges}

As a regional hub, Kenya faces many challenges ranging from pressures exerted by master states and their institutions to global non-state forces operators. The threat from big powers is partly over interpretation of who should determine what Kenya's interests are and how to advance and protect them. North America and the European Union are threats to Kenya's national interests because their officials purport to tell Kenyans what they have to do, and that is not always in Kenya's security or national interest.

The master states operate through such agencies as the international media, NGOs, Civil Society bodies, as well as international financial institutions. The international media and research organizations often set the agenda on the line to be taken towards a given country, or they get it from officials in master states, and once they publicise, it is picked up surrogate local media, NGOs and Civil Society activists. Organisations from master states, often government or public funded, have programme officers who advise the activists on what to agitate about. These are therefore instruments of foreign control and those protecting national interests should know how to deal with them.

Sometimes, such activists are used to condemn their own countries on behalf of the master states. This happens even when the country is a victim of orchestrated attacks meant for someone else. Kenya, for instance, was a secondary victim of international terrorism because it was closely identified with the United States, United Kingdom, and Israel. A secondary target is one that is easier to hit at in order to harm the primary target. Yet the United States had the audacity to deny this reality and in effect try to blame Kenya for being attacked by the terrorists. It then demanded that Kenya pass a law that was patently wrong and insisted that that was what Kenya needed. Because Kenya differed on that and on the Anglo-American invasion of Iraq, not to mention the WTO, it became a double victim first of terrorism and second of its supposed "friends."

International terrorism knows no state boundaries but it is not the only problem. There is also the issue of drug trafficking which is a security as well as socio-economic threat to 
the country. Drug barons are powerful within countries and internationally and destroy the youth. Increasingly, Kenyan youth have become impotent because of various drugs and this affect economic productivity. The future of the country is thus systematically ruined through drugs.

\section{Conclusion;}

Discussions on national security and national interests, therefore, can take many angles but what is required is clarity on the part of those entrusted with safeguarding a country's well being. There are core interests that must be protected and these include the sovereignty of the people and the state, the right to determine own interests, economic well being, and provision of security. There are threats to be encountered from other countries as well as from non-state forces which come in many guises. These can be in the form of terrorism, drug trafficking, and small arms proliferation. They can also be from "friends" who treat Africans as if they are perpetual children. Sometimes, the threat is from the citizens who inadvertently serve foreign interests. 